\title{
Original Paper \\ Endosperm development in Dyckia pseudococcinea (Pitcairnioideae - Bromeliaceae)
}

\author{
Simone Petrucci Mendes ${ }^{1,3}$, Cecília Goncalves da Costa $^{2,4}$ \& Karen Lucia Gama De Toni ${ }^{2,5,6}$
}

\begin{abstract}
Dyckia pseudococcinea is a threatened species endemic to the restingas of the Atlantic Forest, an area under strong anthropic impact. From the perspective of conservation, plant embryology is interesting by the variety of approaches for in vitro culture of seedlings. With this in mind, the present study describes the endospermogenesis of $D$. pseudococcinea to provide data for conservation studies and indicate characters that may contribute to the systematics of Pitcairnioideae. Using anatomical analysis, samples of flowers and fruits at different developmental stages were analyzed. We observed the establishment of the primary endosperm nucleus and then the primary endosperm cell (PEC). Upon expansion of the central vacuole of PEC, nuclei migrate to the chalazal, peripheral, and micropylar domains. An early centripetal cellularization begins in the chalazal region, characterizing the endosperm as coenocytic/multicellular type. With cellularization, the endosperm enfolds the embryo. In addition, in the outermost layer of the endosperm, an aleurone layer is visible. These observations allowed some embryological characters to be identified, thus helping to clarify the systematic relationships of Pitcairnioideae and also the genus Dyckia, such as the presence of hypostasis, the persistence of the antipodals and synergids during the early stages of endospermogenesis and coenocytic/multicellular endospermogenesis. Having established the details of endospermogenesis, we then set forth guidelines for the development of in vitro culture protocols aimed at the conservation of D. pseudococcinea, an endangered Bromeliad species of the Atlantic Forest.

Key words: Bromeliaceae, coenocytic/multicellular endosperm, Dyckia pseudococcinea, Pitcairnioideae, plant embryology.

Resumo

Dyckia pseudococcinea é uma espécie endêmica e ameaçada das restingas da Mata Atlântica, uma área sob forte impacto antrópico. Do ponto de vista da conservação, a embriologia vegetal é interessante pela variedade de abordagens para o cultivo in vitro. A partir disso, o presente estudo descreve o endospermogênese de $D$. pseudococcinea para fornecer dados para estudos de conservação e indicar caracteres que pode contribuir para a sistemática de Pitcairnioideae. Usando análises anatômicas, amostras de flores e frutos em diferentes estágios de desenvolvimento foram analisados. Foi observado o estabelecimento do endosperma primário núcleo e, em seguida, a célula endosperma primária (PEC). Após a expansão do vacúolo central do PEC, núcleos migram para os domínios calazal, periférico e micropilar. Uma celularização centrípeta precoce se inicia na região calazal, caracterizando o endosperma como do tipo cenocítico/multicelular. Com a celularização, o endosperma envolve o embrião. Além disso, na camada mais externa do endosperma, uma camada de aleurona é visível. Essas observações permitiram a identificação de alguns caracteres embriológicos, ajudando a esclarecer as relações sistemáticas de Pitcairnioideae e também do gênero Dyckia, como a presença de hipóstase, a persistência dos antípodas e sinérgides durante as fases iniciais e cenocítico/multicelular da endospermogênese. Tendo assim estabelecido os detalhes da endospermogênese, apresentamos diretrizes para o desenvolvimento de protocolos de cultura in vitro visando à conservação de D. pseudococcinea, uma espécie de bromélia ameaçada de extinção da Mata Atlântica. Palavras-chave: Bromeliaceae, endosperma cenocítico/multicelular, Dyckia pseudococcinea, Pitcairnioideae, embriologia vegetal.
\end{abstract}

\footnotetext{
${ }^{1}$ Univesidade Federal do Rio de Janeiro, Prog. Pós-graduação em Botânica do Museu Nacional, Quinta da Boa Vista, Rio de Janeiro, RJ, Brazil.

${ }^{2}$ Instituto de Pesquisas Jardim Botânico do Rio de Janeiro, Diretoria de Pesquisas, Jardim Botânico, Rio de Janeiro, RJ, Brazil.

${ }^{3}$ ORCID: < https://orcid.org/0000-0002-1772-756X>. ${ }^{4}$ ORCID: $<$ https://orcid.org/0000-0002-5483-1374>. ${ }^{5}$ ORCID: < https://orcid.org/0000-0002-1053-3471>.

${ }^{6}$ Author for correspondence: karen@jbrj.gov.br
} 


\section{Introduction}

Plant embryology has become increasingly useful in terms of conservation, presenting new methodologies for the in vitro culture of endosperm and embryo for seedling production (Moza \& Bhatnagar 2007). Currently, specific hormonal balances are applied to allow the creation of new sporophytes from female or male gametophytes. The induction of organogenesis/embryogenesis has been a major challenge for experimental embryologists. In vitro culture of endosperm for the induction of shoot development is widely used for the generation of seedlings, a strategy useful for the regeneration of natural areas (Shivanna \& Mohan Ram 2005).

Embryological studies in Bromeliaceae are scarce, they involve, e.g., ovule and ovary positioning and morphology, androecium development and pollen viability, as well as embryonic development. These studies were reported by Conceição et al. (2007), Kuhn et al. (2016), Mendes et al. (2010, 2012, 2014, 2016), Oliveira et al. (2015) and Souza et al. (2017).

The first endosperm descriptions were realized by Billings (1904), who classified the endosperm of Tillandsia usneoides Linn. as nuclear type (sensu Schnarf 1929). Subsequently, Lakshmanan (1967) observed in Lindmania penduliflora (C. H. Wright) Stapf. and Pitcairnia funkiana A. Dietr. a helobial endosperm. Rao \& Wee (1979) also observed a helobial endosperm in Ananas comosus (L.) Merr., according to the system proposed by Schnarf(1929). Based on these mentioned studies, Johri et al. (1992) considered the helobial type of endosperm to be a characteristic of Bromeliaceae. In addition, Cecchi Fiordi et al. (2001) described the nature of endosperm reserves and their use in embryo germination of Tillandsia species. And the endosperm ontogeny was recorded in Pitcairnia encholirioides L. B. Sm. (Mendes et al. 2018). As noted, endospermogenesis studies show distinct results among species. Therefore, we need to intensify ontogenetic studies of reproductive structures. According to Varadarajan \& Gilmartin (1988), Palaci et al. (2004) and Sajo et al. (2004), the reproductive structures are potentially useful in the taxonomy of subfamilies and genera of Bromeliaceae.

Dyckia pseudococcinea L.B.Sm. only occurs in the restingas of the municipality of Maricá, Rio de Janeiro state, and it is threatened by natural gas exploration and intense urbanization in the region. These impacts involve changes in the animal and plant communities. The knowledge of the embryological studies, aiming the critical stages in the development, in Angiosperms are useful for the establishment of protocols that allow the production of new seedlings from in vitro culture (Moza \& Bhatnagar 2007). By shedding more light on the life cycle of $D$. pseudococcinea, we aim to establish guidelines through endosperm ontogeny that will lead to the conservation of this endemic species, as already highlighted in Mendes et al. $(2010,2012)$ with respect to the development of androecium, gynoecium and embryogenesis. The present study will describe the endospermogenesis of Dyckia pseudococcinea in anticipation of reaching outcomes that will provide data for future conservation studies. We will further suggest characters that may contribute to the systematics of Pitcairnioideae.

\section{Materials and Methods}

Fruits at different stages of development of $D$. pseudococcinea were collected from different individuals at the Restinga de Ericaceae (Fig. 1a-b) in the municipality of Maricá, Rio de Janeiro state, as well as specimens grown in the Arboretum of the Rio de Janeiro Botanical Garden (Fig. 1c-d). Samples of material collected in the municipality of Maricá were deposited in the herbarium of the Rio de Janeiro Botanical Garden under registration RB 374.208.

Dyckia pseudococcinea is a rupicolous plant propagated through a stout basal shoot, which presents many leaves in a rosette about $40 \mathrm{~cm}$ in diameter (Fig. 1b). The leaf blades measure 20-30 $\times 1-18 \mathrm{~cm}$, presenting margins spinose with retrorse trichomes $1.5-2 \mathrm{~mm}$ long. The inflorescence is simple, racemose and erect with 38 to 65 flowers (Fig. 1c). The reddish floral bracts and sepals make contrast with the orange petals. The androecium has six stamens included, and the anthers have longitudinal dehiscence. The gynoecium presents a trilocular ovary, measuring approximately $7 \mathrm{~mm}$ in length with many ovules per locule. The fruits have winged seeds about $3 \mathrm{~mm}$ long (adapted from Forzza \& Silva 2004).

The collected botanical material was fixed in $2.5 \%$ glutaraldehyde in $0.1 \mathrm{M}$ sodium phosphate buffer, pH 7.2 (Gabriel 1982). After fixation, the material was washed in $0.1 \mathrm{M}$ sodium phosphate buffer at $\mathrm{pH} 7.2$, and dehydrated in an ethanol series. The samples were embedded in hydroxyethylmethacrylate, according to Gerrits $\&$ Smid (1983). Sections 2-3 $\mu \mathrm{m}$ each were cut 
on a Shandon Hypercut microtome in transverse and longitudinal planes. Sections were adhered to glass slides and stained with $0.05 \%$ toluidine blue $\mathrm{O}$ (O'Brien et al. 1965). Histochemical tests were performed: lugol (Sass 1951) for starch detection; sudan IV (Gerlach 1984) and sudan Black B (Harris \& Oparka 1994) for total lipids; Periodic Acid-Schiff Reagent (PAS) (O'Brien \& McCully 1981) for the detection of total polysaccharides; and Bright Coomassie blue (Cawood et al. 1978) for proteins. Observations and image acquisition were performed using an Olympus BX-50 light microscope equipped with a CoolsnapPro digital camera.

\section{Results}

With fertilization, the plasmogamy of one male gamete was observed, together with the secondary nucleus of a female gametophyte (Fig. 2a). This secondary nucleus was formed with the fusion of the polar nuclei. Karyogamy then occurred, followed by the formation of the primary endosperm nucleus (Fig. 2b). During this process, remnants of the antipodals were seen in the chalazal region (Fig. 2b).

Afterwards, the primary endosperm nucleus presented its first karyokinesis. After that, new nuclear divisions were observed. At this stage, an expanding central vacuole was present, and the nuclei migrated to the chalazal, peripheral, and micropylar domains (Fig. 2c), characterizing the primary endosperm cell. This process preceded the first cell divisions of the sporophytic embryo (Fig. 2c).

Parallel to karyokinesis and central vacuole expansion, digestion of the nucellus layers (Fig. 2d) was observed, and this event characterized the end of the coenocytic phase of endosperm development.

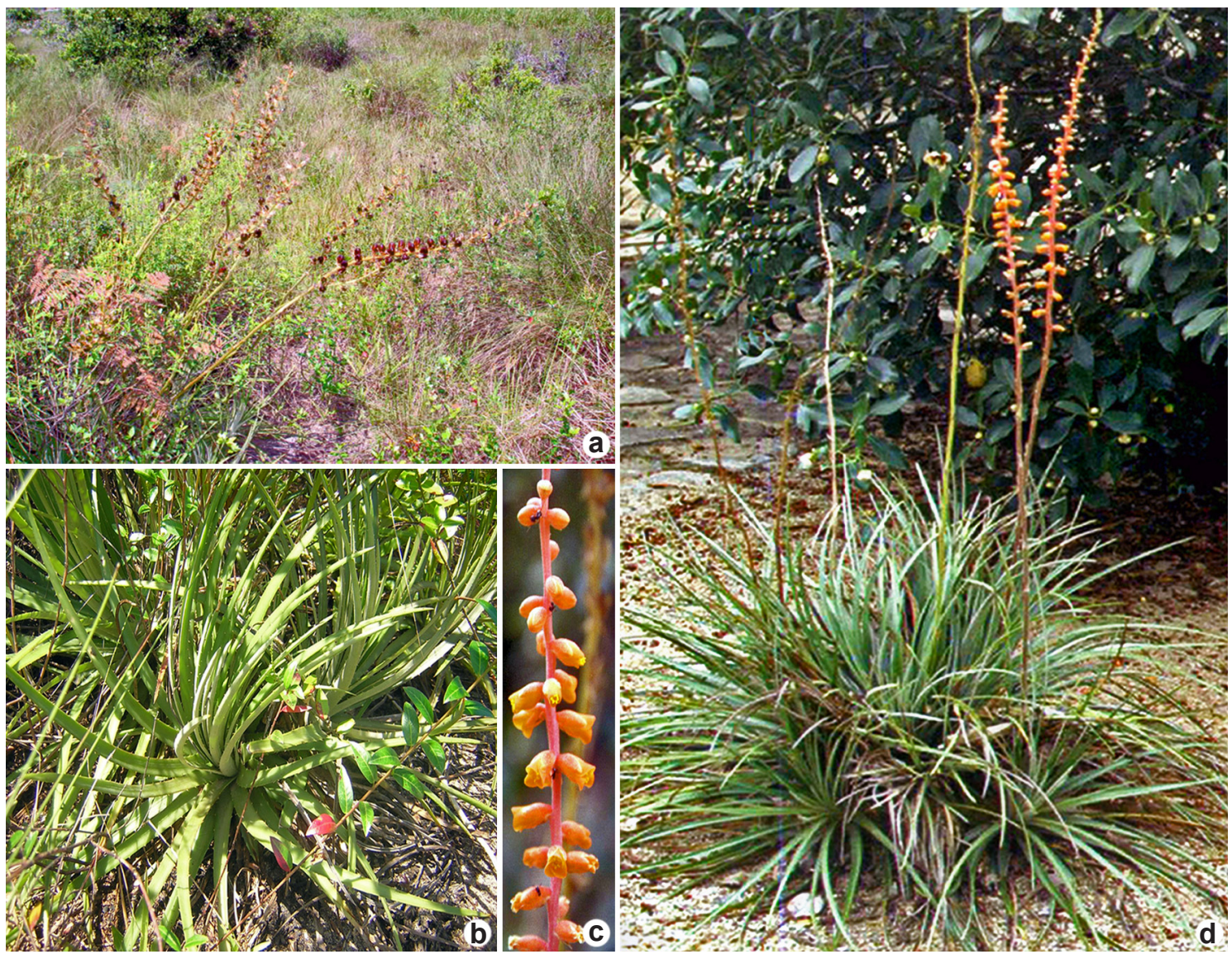

Figure 1 - a-d. Individuals of Dyckia pseudococcinea - a. fruiting individuals in the Ericaceae restinga, municipality of Maricá, Rio de Janeiro state; b. detail of a specimen; c. inflorescence detail; d. specimen in Arboretum of Rio de Janeiro Botanical Garden. Scale bar: $\mathrm{c}=2 \mathrm{~cm}$. 

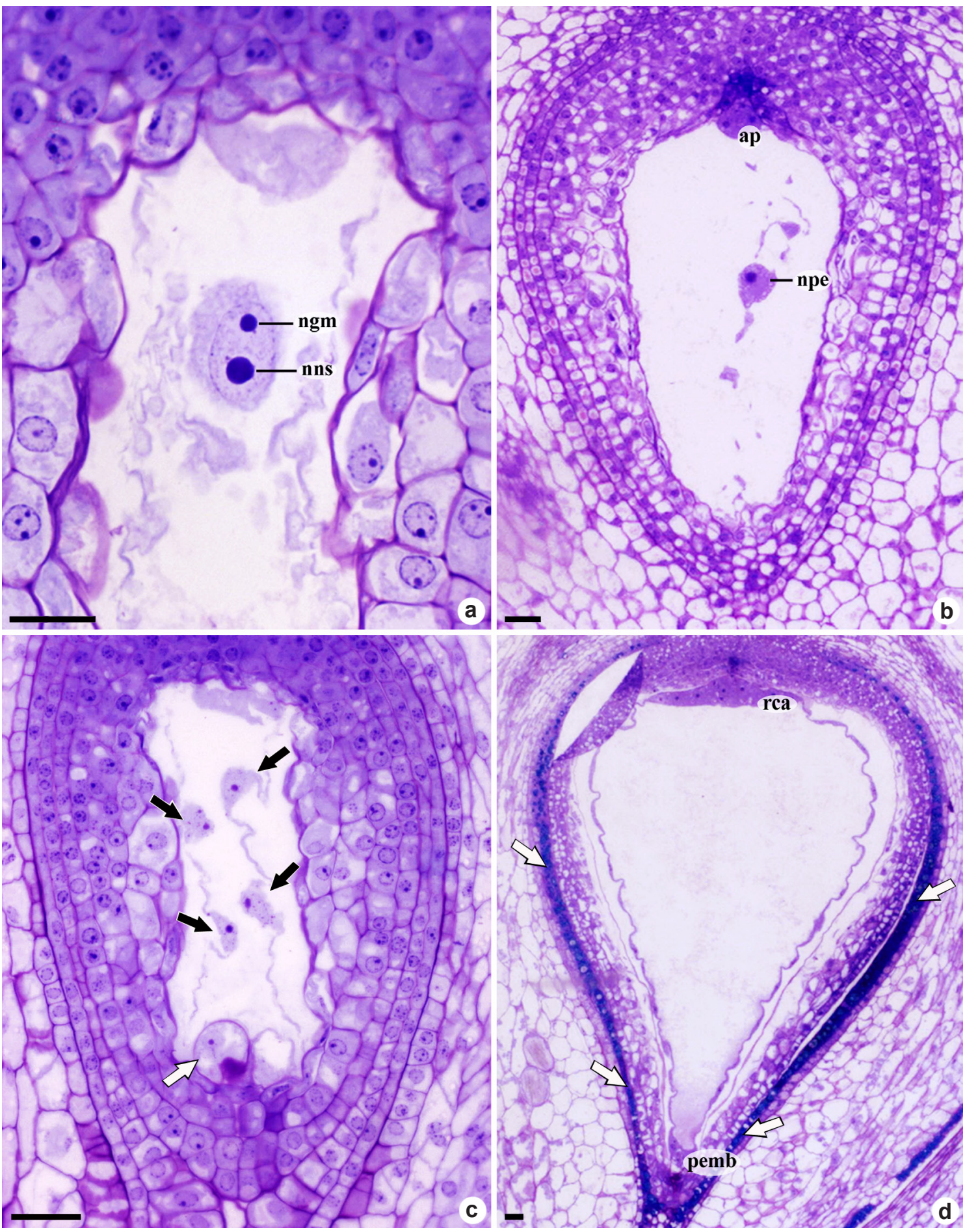

Figure 2 - a-d. Endospermogenesis of Dyckia pseudococcinea (early developmental stages) - a. detail of the one male gamete (ngm) with the secondary nucleus of the female gametophyte (nns); b. primary endosperm nucleus (npe) and remnant antipodals (ap); c. nuclei of primary endosperm cell (black arrows) and zygote (white arrows); d. vacuole expansion of the primary endosperm cell and the differentiation of chalazal domain (rca). Presence of remnants of inner integument and tetracellular proembryo (pemb). Scale bar: $b=50 \mu \mathrm{m} ; \mathrm{a}, \mathrm{c}, \mathrm{d}=100 \mu \mathrm{m}$. All sections are transversal. 
An early cellularization then began in the chalazal region (Fig. 2d) with the formation of the first layer of endosperm cells (Fig. 3a). Subsequent to the formation of this layer, we noted the continuation of the cellularization process, which is considered centripetal (Fig. 3b-c). Such newly formed cells may undergo anticlinal divisions (Fig. $3 \mathrm{~d}$ ) in order to accompany the continuous growth of the endosperm. As this process continues, along with cellularization (Fig. 3c-d), it was possible to observe a larger number of cell layers in the endosperm and a small noncellular central region (Fig. 3e).

With cellularization, the endosperm enfolds the embryo completely, and at this stage, mitotic divisions can be visualized. In the outermost layer of the endosperm, the differentiation of its cells could also be visualized. These cells were smaller with denser cytoplasm than the innermost layers (Fig. 3e). At the end of cellularization, the endosperm was at the multicellular stage (Fig. 3f), and most cell divisions were periclinal (Fig. 3f). At this stage, the number of layers of the nucellus was reduced, owing to endosperm digestion (Fig. 3e-f).

In parallel, we noted the deposition of phenolic substances in the cells of the inner integument (Fig. 3c), which persisted until endosperm maturation (Figs. 3b-e; 4a).

With the end of mitotic division, it was possible to observe the process of reserve allocation. Histochemical analyses of the endosperm revealed large amounts of starch grains inside the cells (Fig. 4b), except the outermost layer. Starch grains are considered composite grains, consisting of six to eight granules each (Fig. 4c). We also noted the abundance of polysaccharides (Fig. 4d) and proteins (Fig. 4e). The presence of lipids was observed only in the cells of the outermost layer of the endosperm (Fig. 4f-g), always at later stages of development.

\section{Discussion}

The endosperm, or xenophyte, is considered an auxiliary generation of Angiosperms, acting as a reserve tissue within the seed (Cocucci \& Mariath 1995). From the ontogenetic view, the establishment of the endosperm begins from the appearance of the primary endosperm nucleus, as a result of fertilization of the secondary nucleus of the female gametophyte by one of the male gametes (Batygina 2006). Subsequent to this process, the primary endosperm nucleus may follow distinct patterns of divisions, which were described by Schnarf(1929). This author classifies the formation of the endosperm into three types: nuclear, cellular and helobial, the distinctions mainly attributed to the cellularization process. Di Fulvio (1983) developed a new classification system, called EODP, based on the variations occurring during cellular endospermogenesis, in which "E" refers to the type of endospermogenesis, "O" to the orientation of the first cell wall, " $\mathrm{D}$ " to the destination of the two daughter cells, and "P" to the position of the cell walls of the second mitotic cycle. To classify the different types of cellular endospermogenesis patterns, Lersten (2004) proposed four distinct types of development: multicellular, coenocytic/multicellular, helobial and coenocytic.

In the present study, we agree with Lersten (2004), who classified Dyckia pseudococcinea endosperm as the coenocytic/multicellular type, an early multinucleate and a later multicellular phase. This pattern of development corresponds to the nuclear type sensu Schnarf (1929), and, according to Di Fulvio \& Cocucci (1986), also to the nuclear megatype, isopolar type, and peripheral subtype.

In Bromeliaceae, the presence of an early multinucleated phase with subsequent cellularization was also identified in Tillandsia usneoides (Billings 1904). However, the development of the helobial type, also cited in the general description for the family (Johri et al. 1992), was observed in Lindmania penduliflora, Pitcairnia funkiana (Lakshmanan 1967), and Ananas comosus (Wee \& Rao 1974; Rao \& Wee 1979). Therefore, among the records related to endospermogenesis in Bromeliaceae and, particularly, the subfamily Pitcairnioideae, we see a divergence in the results obtained. Despite the occurrence of records of different types of endospermogenesis for the same family (Swamy \& Ganapathy 1957), or even a single genus (Svensson 1925), evidence suggests the need to establish a general pattern for the family or subfamily.

Lersten (2004) considers the helobial type a variation of the coenocytic/multicellular type. According to this author, after the initial formation of two cells, the cells closest to the micropyle follow the same pattern of development as that presented by the coenocytic/multicellular type. This inference may suggest a helobial type derivation from the coenocytic/multicellular type, indicating an evolutionary trend in Bromeliaceae.

Davis (1966) recognized coenocytic/ multicellular endospermogenesis (sensu Lersten 




Figure 3 - a-f. Endospermogenesis of Dyckia pseudococcinea (cellularization process) - a. detail of the first cellular layer of endosperm cells in the chalazal domain ( $\mathrm{rca}$ ); b. cellularization process, showing phenolic compounds in the inner integument cells (white arrows); c-d. later developmental stages of the cellularization process, indicating the remnants of nucellus (nu) and the presence of phenolic compounds in the inner integument cells (white arrows) $-\mathrm{d}$. black arrows indicate the anticlinal divisions in the external cells of endosperm; e. ending of the cellularization process, evidencing the remnant nucellus cells (nu), and the beginning of external endosperm layer differentiation (black arrows). Phenolic compounds also evident in the remnants of inner integument (white arrows) and a noncellular central region (asterisk); f. general view of the multicellular endosperm, evidencing mitotic division (head arrows), distinct outer cellular layer of the endosperm (black arrows), remnant nucellus (nu) and the phenolic compounds (white arrows). Scale bar: a-f $=100 \mu \mathrm{m}$. All sections are transversal. 
2004) in 161 of the 288 Angiosperm families analyzed in their study. This type is common to both dicotyledons (Maheshwari \& Khan 1953; Ganapathy 1956; Kapoor \& Tandon 1964; Webb \& Gunning 1991; Brown et al. 1999) and monocotyledons (Venkateswarlu et al. 1980; Gopal \& Mohan Ram 1987; Sven \& Greilhuber 1987; Kowles \& Phillips 1988; Bouman \& Devente 1992; Johri et al. 1992; Olsen et al. 1995; Raghavan 2000; Olsen 2004). Although the monocotyledons exhibit mainly the coenocytic/multicellular and helobial developmental types, the Araceae and Lemnaceae families, in which endospermogenesis is multicellular (Bhojwani \& Bhatnagar 1999), are an exception.

From the identification of the types of endospermogenesis in the Angiosperms, many authors attempted to elucidate their phylogenetic relationships. Schnarf (1929), for example, by the observation of karyokinesis in the gymnosperms' gynophyte, interpreted the nuclear type as primitive. Later, Sporne $(1954,1967)$ attributed characters otherwise considered primitive among the dicotyledons to the nuclear endosperm. Based on this evidence, the observations of Schnarf (1929) were corroborated. However, Swamy \& Ganapathy (1957) criticized Sporne's (1954) conclusions, arguing that his analysis may have been distorted based on his inclusion of the helobial type in the nuclear endosperm category and the selection of poorly defined phylogenetic characters. In a new analysis, these authors relate the types of vascular bundle, a character with a reliable evolutionary line, to the types of nuclear and cellular endosperm, and they conclude that the cellular type is ancestral to nuclear endosperm in dicotyledons.

Among the Pitcairnioideae, the genus Dyckia is considered of recent origin in relation to others of the subfamily (Givnish et al. 2006). Although Dyckia presents a coenocytic/multicellular endosperm, it is considered by Lerstern (2004) as a basal evolutionary condition. As previously mentioned, the coenocytic/multicellular or nuclear type is considered common among monocotyledons. However, most of the Bromeliaceae samples studied present a helobial endosperm, characterizing a synapomorphy for the group. Based on this premise, the coenocytic/multicellular endosperm observed in D. pseudococcinea can be interpreted as a reversion for the genus.

According to Newcomb (1973), the endosperm, during its initial development, is metabolically active, but does not accumulate reserve substances. Raghavan (2000) and Lersten (2004) interpret the early development of the endosperm as a way to provide nutrients and hormones to the zygote. However, Heuser (1999) suggests that this temporal difference occurs to the detriment of individuality between distinctly different plants during their development. Early establishment of the endosperm relative to the embryo in D. pseudococcinea may be related nutrition, as mentioned by Raghavan (2000) and Lersten (2004).

As previously described, the development of the endosperm in D. pseudococcinea begins with the process of centripetal cellularization in the chalazal region. This process results in the formation of endosperm cells located near the antipodal cells and the hypostasis, which can be interpreted as an advantage compared to the inverse condition, i.e., cellularization in the micropylar region. This advantage could also be related to nutrition (Brown et al. 1996b; Engell 1994). In addition, cellularization can be interpreted as an advantageous process since it consists of a new means of allocating reserve substances, both for the embryo and the seed during germination (Newcomb 1973).

During the cellularization process in D. pseudococcinea, the presence of phenolic compounds in the single remaining layer of the inner integument becomes evident. According to Danilova (2006), the deposition of these compounds is indicative of the differentiation of the seed coat. The presence of compounds of this nature, besides increasing the resistance of the seed coat (Swain 1979), confers protection against predation or herbivory of insects and microorganisms, such as bacteria and fungi (Boesewinkel \& Bouman 1984). Further, these compounds can act as a barrier against the digestion of endosperm cells on the seed coat.

Some studies (Brown et al. 1996a, b; Brown et al. 1999; Olsen et al. 1995; Olsen 2001, 2004) have evidenced the processes involved in endosperm cellularization. All demonstrate a cellularization pattern by compartmentalization, which is characterized by a series of events that includes the organization of the cytoplasm in nuclear-cytoplasmic domains, deposition of anticlinal walls, mitosis and deposition of periclinal walls, resulting in the compartmentalization of the first "layer" of the coenocyte. Some repetitions of this cycle complete the cellularization of the endosperm. It is assumed that this pattern, 

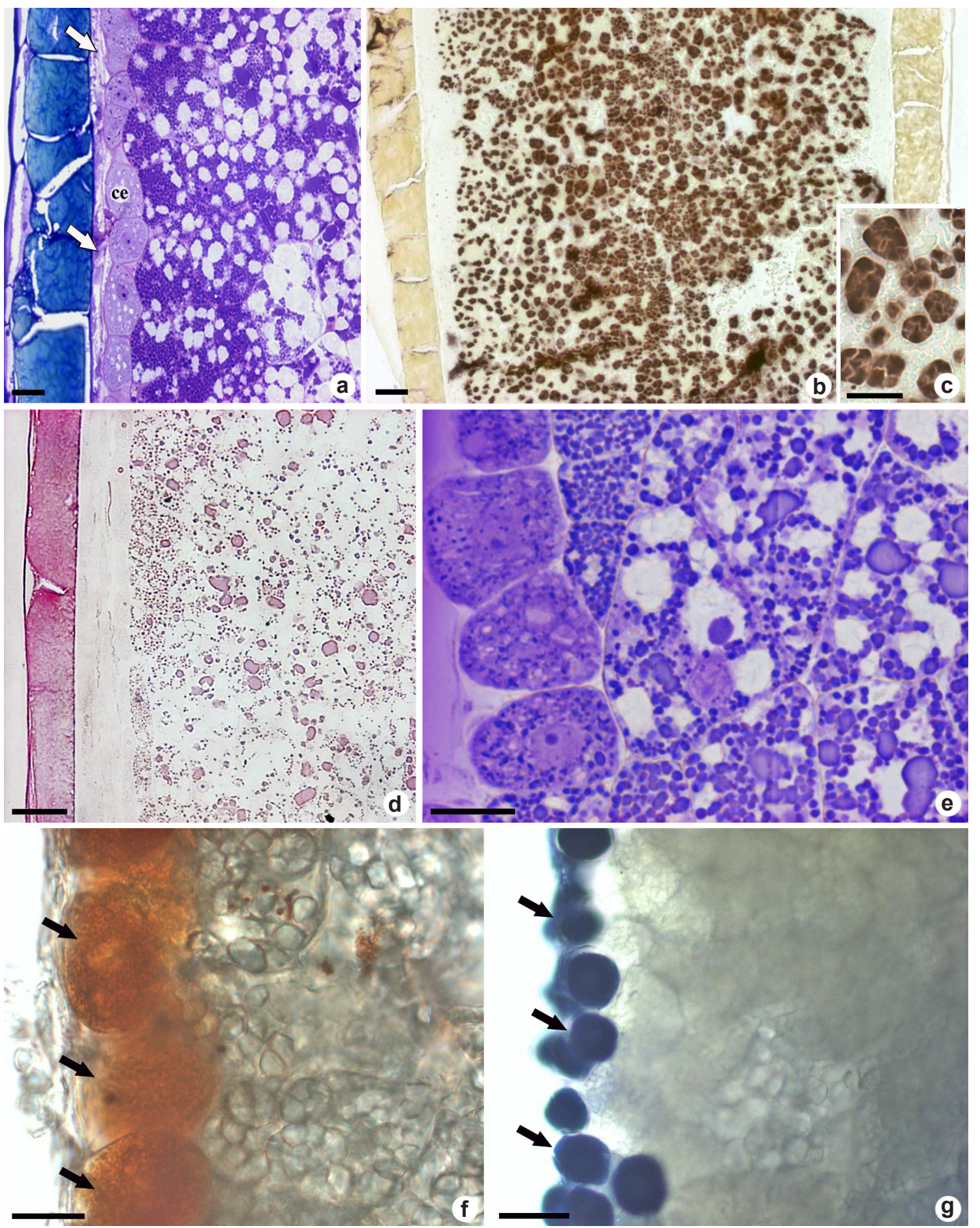

Figure 4 - a-g. Endospermogenesis of Dyckia pseudococcinea (histochemical tests) - a. outer endosperm region, evidencing the differentiated cell layer (ce). Note the remnants of the nucellus (arrows) - toluidine blue $0.05 \%$; b-c. starch grains in the endosperm cells - lugol; d. multicellular endosperm, showing polysaccharides - PAS; e. multicellular endosperm, showing proteins - bright Coomassie blue; f-g. fresh section of endosperm, evidencing lipids (arrows) - $\mathrm{f}$. Sudan IV; g. Sudan Black B. Scale bar: c, f, g=50 $\mu \mathrm{m} ; \mathrm{a}, \mathrm{b}, \mathrm{d}, \mathrm{e}=100 \mu \mathrm{m}$. All sections are transversal. 
in general, regulates the cellularization of the endosperm in D. pseudococcinea by the similarity with Oryza sativa L. (Brown et al. 1996a), also described as having a centripetal pattern. Apart from this, centripetal cellularization is characteristic of the nuclear endosperm and a conserved character among Angiosperms (Brown et al. 1999).

Furthermore, the presence of a distinct external cell layer, consisting of cubic cells containing denser cytoplasm than the others, is observed in the mature endosperm of $D$. pseudococcinea. In the case of Mayacaceae, Restionaceae (Johri et al. 1992), and in most of the cereals, this layer is distinguished as the aleurone layer (Olsen et al. 1995; Raghavan 2000). The aleurone is characterized by its proteinaceous nature, normally observed in the form of granules (Raven et al. 1999). However, variations in the number of layers may occur, with one to many in rice (Olsen 2004), two to three in barley (Kvaale \& Olsen 1986; Raghavan 2000; Olsen 2004), and a sublayer of aleurone in Zea mays (van Lammeren et al. 2006).

The distinction of an aleurone layer was suggested by Szidat (1922) to Bromeliaceae and later recorded in Ananas sativus Schult. (Holmes 1933), A. comosus (Wee \& Rao 1974), Tillandsia juncea Willd. (Cecchi Fiordi et al. 2001) and Catopsis paniculata E. Morren (Palaci et al. 2004). Similar to D. pseudococcinea, the mentioned species present protein granules in this layer. In addition to proteins, Cecchi Fiordi et al. (2001) detected the abundant presence of lipids owing to lipid droplets located around the aleurone grains. These authors also recorded the abundance of calcium oxalate crystals, but such oxalate crystals were not seen in D. pseudococcinea.

In addition to polysaccharides and proteins, the other cells of the endosperm of $D$. pseudococcinea show a high concentration of starch grains, similar to that described for Tillandsia seeds (Cecchi Fiordi et al. 2001). The storage of these compounds is closely related to the differentiation of the endosperm into reserve tissue, and its accumulation at this site allows its seeds to be classified as endospermic based on the types proposed by Cocucci (2004).

Currently, the morphogenetic potential of the endosperm to propagate new plants is known (Shivanna \& Mohan Ram 2005). The specific knowledge of the stages of development of the endosperm in D. pseudococcinea becomes useful for the establishment of protocols that allow the production of new seedlings from in vitro culture. In addition, based on this knowledge, it will be possible to clarify the genetic and molecular processes that regulate the specific stages of its formation, such as the first division of the primary endosperm nucleus, the peripheral arrangement of the nuclei, the beginning of cellularization, and the synthesis of reserve substances.

Some records indicate that in vitro organogenesis from endosperm cells is induced by regulatory factors from the embryo (Johri 1984), while others emphasize the independence of these processes in relation to the embryo (Cheema \& Mehra 1982). Prior knowledge of embryonic development (Mendes et al. 2010) and endosperm in D. pseudococcinea may clarify the influence of the embryo in relation to morphogenetic processes of the endosperm.

Studies reporting on the relationship between endosperm and embryo during seed development in D. pseudococcinea may be useful both in the establishment of conservation protocols and storage of seeds, as well as in experiments that address their germination.

Moreover, the increase in embryological studies used to circumscribe taxa demonstrates the potential of embryological studies to elucidate taxonomic issues among the Angiosperm groups (Raghavan 2004). Indeed, embryological characteristics, such as the presence of hypostasis, the persistence of the antipodals and synergids during the early stages of endospermogenesis, and coenocytic/multicellular endospermogenesis, were identified in the present study. It is anticipated that such characteristics may help clarify the systematic relationships of Pitcairnioideae and the genus Dyckia. Other characters were also identified, such as the peripheral positioning of the initial nuclei of the endosperm, the centripetal cellularization of the endosperm, albuminous seeds and asteraceous embryogenesis. However, these latter characteristics resemble other descriptions in Bromeliaceae species and were not considered sufficiently informative for the systematics of the group.

\section{Acknowledgements}

We thank the Museu Nacional (MN), Universidade Federal do Rio de Janeiro (UFRJ), Instituto de Pesquisas Jardim Botânico do Rio de Janeiro (JBRJ), Coordenadoria de Aperfeiçoamento de Pessoal de Nível Superior (CAPES), Fundação 
de Amparo à Pesquisa do Estado do Rio de Janeiro (FAPERJ - E-26/110.810/2013), and Fundação de Amparo à Pesquisa do Estado do Rio Grande do Sul (FAPERGS), for funding this study.

\section{References}

Batygina TB (2006) Embryology of Flowering Plants - Terminology and Concepts. Volume II - Seed. Science Publishers, Enfield. 786p.

Bhojwani SS \& Bhatnagar SP (1999) The Embryology of Angiosperms. $4^{\text {th }}$ Revised \& Enlarged Edition. Vikas Publishing house PVT LTD, New Delhi. 372p.

Billings FH (1904) A study of Tillandsia usneoides. Botanical Gazette 38: 99-121.

Boesewinkel FD \& Bouman F (1984) The seed: structure. In: Johri BM (ed.) Embryology of Angiosperms. Springer-Verlag, Berlin. Pp. 567-610.

BoumanF \& DeventeN(1992)Acomparison of the structure of ovules and seeds in Stemona (Stemonaceae) and Pentastemona (Pentastemonaceae). Blumea 36: 501-514.

Brown RC, Lemmon BE \& Olsen O-A (1996a) Development of the endosperm in rice (Oryza sativa L.): cellularization. Journal of Plant Research 109: 301-313.

Brown RC, Lemmon BE \& Olsen O-A (1996b) Polarization predicts the pattern of cellularization in cereal endosperm. Protoplasma 192: 168-177.

Brown R, Lemmon, BE, Nguyen H \& Olsen O-A (1999) Development of endosperm in Arabidopsis thaliana. Sexual Plant Reproduction 12: 32-42.

Cawood AH, Potter U \& Dickinson HG (1978) An evaluation of Coomassie Brilliant Blue as a stain for quantitative microdensitometry of protein in section. Journal of Histochemistry and Cytochemistry 36: 645-650.

Cecchi Fiordi A, Palandri MR, Turicchia S, Tani G \& Di Falco P (2001). Characterization of the seed reserves in Tillandsia (Bromeliaceae) and ultrastructural aspects of their use at germination. Caryologia 54: 1-16.

Cheema GS \& Mehra PN (1982) Morphogenesis in endosperm cultures. Proceedings of the $5^{\text {th }}$ International Congress of Plant Tissue and Cell Culture. Japanese Association for Plant Tissue Culture, Tokio. Pp. 111-112.

Cocucci AE \& Mariath JEA (1995) Sexualidade das plantas. Ciência Hoje 18: 50-61.

Cocucci AE (2004) Morphogenetic seed types of Spermatophyta. Plant Systematics and Evolution 250: $1-6$.

Conceição SP, De Toni KLG \& Costa CG (2007) Particularidades do nucelo de Dyckia pseudococcinea L.B.Smith (Bromeliaceae). Revista Brasileira de Biociências 5: 846-848.

Danilova MF (2006) Seed coat. In: Batygina TB (ed.) Embryology of flowering plants - Terminology and Concepts. Vol. II - Seed. Science Publishers, Enfield. Pp. 424-426.

Davis GL (1966) Systematic embryology of the Angiosperms. Jonh Wiley Sons, New York. 528p.

Di Fulvio TE (1983) Los "tipos" de endosperma y de haustorios endospermicos. Su clasificacion. Kurtziana 16: 7-31.

Di Fulvio TE \& Cocucci AE (1986) La endospermogenesis nuclear y el sistema EODP. Kurtziana 18: 13-21.

Engell K (1994) Embryology of barley. IV. Ultrastructure of the antipodal cells of Hordeum vulgare L. cv. Bomi before and after fertilization of the egg cell. Sexual Plant Reproduction 7: 333-346.

Forzza RC \& Silva BR (2004) A new species of Dyckia (Bromeliaceae) from Rio de Janeiro state, Brazil. Novon 4: 168-170.

Gabriel BL (1982) Biological Electron Microscopy. Van Nostrand Reinhold, New York. 264p.

Ganapathy PM (1956) Female gametophyte and endosperm of Ophiorrhiza mungos L. Journal of the Madras University, Section B 26: 589-592.

Gerlach D (1984) Botanische Mikrotechnik. Georg Thieme Verlag, Stuttgart. 311p.

Gerrits PO \& Smid L (1983) A new, lesstoxic polymerization system for the embedding of soft tissues in glycol methacrylate and subsequent preparing of serial sections. Journal of Microscopy 132: 81-85.

Givnish JG, Millam KC, Berry PE \& Sytsma KJ (2006) Phylogeny, adaptive radiation, and historical biogeography of Bromeliaceae inferred from $n d h \mathrm{~F}$ sequence data. Aliso 23: 3-26.

Gopal BH \& Mohan Ram HY (1987) Fruit development and structure in some Indian bamboos. Annals of Botany 60: 477-483.

Harris N \& Oparka KJ (1994) Plant cell biology - a practical approach. Oxford University Press, Oxford. 360p.

Heuser ED (1999) Embriogênese em Ilex paraguariensis St. Hil. Aspectos do suspensor e endosperma. Tese de Doutorado. Universidade Federal do Rio Grande do Sul, Porto Alegre. 145p.

Holmes LE (1933) Studies in the morphology and biochemistry of the pineapple. II. Reserves in the seeds of two genera of the Bromeliaceae and of various pineapple hybrids. New Phytologist 32: 382-392.

Johri BM (1984) Embryology of angiosperms. SpringerVerlag, Berlin. 830p.

Johri BM, Ambegaokar KB \& Srivastava PS (1992) Comparative embryology of angiosperms. Vol. 2. Springer-Verlag, Berlin, Heidelberg. Pp. 615-1221.

Kapoor BM \& Tandon SL (1964) Contributions to the cytology of endosperm in some angiosperms. VII. Vicia faba L. Caryologia 17: 471-479.

Kowles RV \& Phillips RL (1988) Endosperm development in maize. International Review of Cytology 112: 97-136. 
Kuhn SA, Nogueira FM, Fagundes NF \& Mariath JEA (2016) Morphoanatomy of the ovary and ovule in Bromeliaceae subfamily Tillandsioideae and its systematic relevance. Botanical Journal of the Linnean Society 181: 343-361.

Kvaale A \& Olsen OA (1986) Rates of cell division in developing barley endosperms. Annals of Botany 57: 829-833.

Lakshmanan KK (1967) Embryological studies in Bromeliaceae. I. Lindmania penduliflora (C.H. Wright) Stapf. Proceedings of the Indian Academy of Sciences, Section B 65: 49-55.

Lersten NR (2004) Flowering plant embryology with emphasis on economic species. Blackwell Publishing, Oxford. 224p.

Maheshwari P \& Khan R (1953) Development of the embryo sac, endosperm and embryo in Isomeris arborea - a reinvestigation. Phytomorphology 3: 446-459.

Mendes SP, Costa CG \& De Toni KLG (2010) Embryo development of Dyckia pseudococcinea (Pitcairnioideae-Bromeliaceae), an endangered Brazilian species. Australian Journal of Botany 58: 485-492.

Mendes SP, Costa CG \& De Toni KLG (2012) Androecium development in the bromeliad Dyckia pseudococcinea L.B.Sm. (PitcairnioideaeBromeliaceae), an endangered species endemic to Brazil: implications for conservation. Flora 207: 622-627.

Mendes SP, Mastroberti AA, Mariath JEA, Vieira RC \& De Toni KLG (2014) Ovule and female gametophyte development in the Bromeliaceae: an embryological study of Pitcairnia encholirioides. Botany 92: 883-894.

Mendes SP, Duarte-Silva E, Kaltchuk-Santos E, Mariath JEA, Vieira RC \& De Toni KLG (2016) A case of male sterility in the endangered endemic species Pitcairnia encholirioides L.B.Sm. (bromeliaceae) of Brazilian Atlantic Forest Inselbergs. International Journal of Plant Science 177: 498-510.

Mendes SPM, Vieira RC \& De Toni KLG (2018) Embryo and endosperm development in Pitcairnia encholirioides (Pitcairnioideae - Bromeliaceae): an endangered species of the Atlantic Forest. Flora 246-247: 10-18.

Moza MK \& Bhatnagar AK (2007) Plant reproductive biology studies crucial for conservation. Current Science 92: 1207.

Newcomb W (1973) The development of the embryo sac of sunflower Helianthus annuus after fertilization. Canadian Journal of Botany 51: 879-890.

O'Brien TP, Feder N \& McCully ME (1965) Polychromatic staining of plant cell walls by Toluidine Blue O. Protoplasma 59: 368-373.

O'Brien TP \& McCully ME (1981) The study of plant structure principles and select methods. Termarcarphi Pty, Melbourne. 45p.
Oliveira JMS, Martins MS, Dorneles MP \& Freitas CC (2015) Starch distribution in anthers, microspores and pollen grains in Aechmea recurvata (Klotzsch.) L.B.Sm., Dyckia racinae L.B.Sm. and Tillandsia aeranthos (Loisel.) L.B.Sm. (Bromeliaceae). Acta Botanica Brasilica 29: 103-112.

Olsen OA (2001) Endosperm development: Cellularization and cell fate specification. Annual Review of Plant Physiology and Plant Molecular Biology 52: 233-267.

Olsen OA (2004) Nuclear endosperm development in cereals and Arabidopsis thaliana. The Plant Cell 16: S214-S227.

Olsen OA, Brown RC \& Lemmon BE (1995) Pattern and process of wall formation in developing endosperm. BioEssays 17: 803-812.

Palaci CA, Brown GK \& Tuthill DE (2004) The seeds of Catopsis (Bromeliaceae: Tillandsioideae). Systematic Botany 29: 518-527.

Raghavan V (2000) Developmental biology of flowering plants. Springer-Verlag, New York. 354p.

Raghavan V (2004) Plant embryology during and after Panchanan Maheshwari's time - changing face of research in the embryology of flowering plants. Current Science 87: 1660-1665.

Rao AN \& Wee YC (1979) Embryology of the pineapple, Ananas comosus (L.) Merr. New Phytologist 83: 485-497.

Raven PH, Evert RF \& Eichhorn SE (1999) Biology of plants. $6^{\text {th }}$ ed. W.H. Freeman, New York. 944p.

Sajo MG, Prychid CJ \& Rudall PJ (2004) Structure and development of the ovule in Bromeliaceae. Kew Bulletin 59: 261-267.

Sass JE (1951) Botanical microtechnique. State College Press, Ioawa. 228p.

Schnarf K (1929) Embryologie der Angiospermen. Borntraeger, Berlin.

Shivanna KR \& Mohan Ram HY (2005) Contributions of Panchanan Maheshwari's school to Angiosperm embryology through an integrative approach. Current Science 89: 1820-1834.

Souza EH, Souza FVD, Rossi ML, Packer RM, Cruz-Barros Mav \& Martinelli AP (2017) Pollen morphology and viability in Bromeliaceae. Anais da Academia Brasileira de Ciências 89: 3067-3082.

Sporne KR (1954) A note on nuclear endosperm as a primitive character among dicotyledons. Phytomorphology 4: 275-278.

Sporne KR (1967) Nuclear endosperm: an enigma. Phytomorphology 17: 248-251.

Svensson HG (1925) Zur embryologie der Hydrophyllaceen, Borraginaceen und Heliotropiaceen. Dissertation. Uppsala Universitets Årsskrift, Uppsala. 179p.

Swain T (1979) Tanins and lignins. In: Rosenthal GA \& Janzen DH (eds.) Herbivores: their interaction with secondary plant metabolities. Academic Press, New York. Pp. 657-674. 
Swamy BGL \& Ganapathy PM (1957) On endosperm in dicotyledons. Botanical Gazette 119: 47-49.

Szidat L (1922) Die Samen der Bromeliaceen in ihrer Anpassung an den Epiphytismus. Botanische Archives 1: 29-46.

van Lammeren AAM, Kieft H, Ma F \& van Veenendaal WLH (2006) Light microscopic study of endosperm formation in Brassica napus L. In: Batygina TB (ed.) Embryology of flowering plants - terminology and concepts. Vol. II - seed. Science Publishers, Enfield. Pp.128-131.

Varadarajan GS \& Gilmartin AJ (1988) Seed morphology of the subfamily Pitcairnioideae (Bromeliaceae) and its systematics implications. American Journal of Botany 75: 808-818.

Venkateswarlu J, Devi P \& Nirmala A (1980) Embryological studies in Eleutherine plicata Herb. and Belamcanda chinensis Lem. Proceedings Indian of Academy Society (Plant Science) 89: 361-367.

Webb MC \& Gunning BES (1991) The microtubular cytoskeleton during development of the zygote, proembryo and free-nuclear endosperm in Arabidopsis thaliana (L.) Heynh. Planta 184: 187-195.

Wee YC \& Rao AN (1974) Gametophytes and seed development in pineapple. Current Science 43: 171-173. 